\title{
Worldview studies
}

\author{
Mikael Stenmark \\ Department of Theology, Uppsala University, Box 511, 75120 Uppsala, Sweden \\ email: mikael.stenmark@teol.uu.se
}

(Received 25 November 2020; revised 12 March 2021; accepted 14 March 2021)

\begin{abstract}
I argue that philosophers of religion should not merely focus on religions but should pay much more attention to the secular outlooks on life emerging in contemporary society. To compare these outlooks, I suggest that we use the notion of worldview, and contrast religious worldviews with secular worldviews - rather than contrasting religions with nonreligions, which scholars of religion have recently tended to do. Accordingly, religious people should be contrasted with secular people and not with religious 'nones'. I also explore the specific contribution of philosophy of religion to worldviews studies, and discuss why such a contribution is considered controversial within religious studies circles. I contend that it should instead be a legitimate and essential part of the academic study of worldviews.
\end{abstract}

Keywords: worldview; nonreligion; secular; naturalism; theism

With the increased secularization of large parts of the world, there are many people who no longer see themselves as religious. Scholars of religion have been searching for other notions to use to identify such people and what they replace religion with, which often have a family resemblance to the concept of religious believers and religious belief. Frequently, these religious-studies specialists have used the term 'nonreligion', and have called these individuals 'nonbelievers' or 'religious nones.'. (This is the majority view but as we will see, there is also an alternative view emerging within Religious Studies.) However, in the philosophy of religion community, we have often used another notion, one which comprehends both those who see themselves as religious and those who do not. We have employed 'worldviews' as a core analytic concept. In this article, I shall argue that the terminology used in the philosophy of religion is to be preferred to the one typically used in religious studies - and not merely in philosophy but also in the study of religion too. I further maintain that philosophers of religion have not paid sufficient attention to the secular outlooks on life that have recently developed as alternatives to traditional religions, nor to the issue of how to characterize the difference between these two kinds of worldview. We do indeed need to develop a more global philosophy of religion, ${ }^{2}$ but we must also turn the philosophy of religion into a philosophy of worldviews.

This article is structured in such a way that I shall first offer an explication of the notion of worldview and then discuss the difference between religious and secular worldviews. In the process, it will become clear why the term 'secular worldview' is preferable over 'nonreligion', and the term 'secular people' over 'nonreligious people' or 'religious 
nones'. I shall also point out what kind of contribution philosophers of religion might provide to the emerging field of worldview studies.

\section{What is a worldview?}

Ninian Smart was one of the first scholars in the English-speaking world to emphasize the need for a more comprehensive term than 'religion' and to argue for a change of focus in both the philosophy of religion and religious studies. He was, in fact, both a philosopher and a scholar of world religions. (Similar developments and protagonists can be found in other countries such as Germany, Holland, and Sweden.) $)^{3}$ Smart writes:

The English language does not have a term to refer to both traditional religions and ideologies; the best expression is perhaps 'worldviews.' ... The study of religions and secular worldviews - what I have termed 'worldview analysis' - tries to depict the history and nature of the belief and symbols that form a deep part of the structure of human consciousness and society. (Smart (1995a), 2)

Philosophers of religion have, ever since, talked about a worldview as 'a sort of total way of looking at ourselves and our world' (Plantinga (2011), ix) or as 'our overall view of the nature of reality' (Cottingham 2014, 1). In particular, they have used the term to characterize the difference between a theistic worldview (or theism) and a naturalistic worldview (or naturalism).

A substantial number of definitions of worldview have also been offered (for instance, Jeffner (1992), Smart (1995a), Naugle (2002), Vroom (2006), and Sire (2015)). In what follows, I shall, building on previous research I have done (Stenmark (1995), 240f.), propose the definition that I think we should use, and shall explicitly or implicitly explain why it is to be preferred over some of the others and what it can do for us in our study of religions and their secular alternatives. I suggest that by worldview we mean:

the constellation of beliefs, values, and attitudes that people, whether consciously or unconsciously, hold and which constitute their basic understanding of (a) who they are, what the world is like, and what their place in it is, (b) what they should do to live a good and meaningful life, and (c) what they can say, know and rationally believe about these things.

Thereby, two of the three things that a worldview contains are, among others, our ontology - what we take to exist and how these things relate to one another and what properties they have; and our epistemology - what we can know and rationally believe about these things, properties and relations. The third requisite is that a worldview encompasses our ethical or moral stance - the value commitments we express in thought and action. Alternatively, and more precisely, a worldview contains those parts of our ontology, epistemology and ethics that are of central importance for how we understand our lives and live them. A worldview is life orienting: it expresses a particular way of living in the world.

If we understand the idea of a worldview in this sense, it follows that it has a broader application than just to religion. We have here a notion that covers all religions and yet further covers the ways of life of people whether or not they hold a religious outlook on the world. The basic idea is that not all people are religious, but all people have a worldview. They have, or express in their lives, particular attitudes, beliefs, and values about who they (we) are, what the world is like, what their (and our) place in it is, what they 
(or we) must do to live a good life and what they (and we) can know and rationally believe about these things.

By belief, in the definition given above, I mean what people think or assume to be true about the world and our place therein. One might believe that God exists or that everything that exists is ultimately made out of matter, that people have or do not have a free will, that we are basically good or evil, or that there is or is not an afterlife. But worldviews also contain different values about what we should do or avoid doing to live a good life, on both the individual and the collective level. Humanists think that human dignity, and the values and duties that flow from a commitment to that dignity, should shape our worldview. Transhumanists believe that posthuman lives would be better lives: we ought to enhance ourselves. Furthermore, worldviews also include attitudes or stances directed towards the world, other people, or ourselves. We could say, roughly, that these attitudes express our emotional dispositions towards things, properties, processes, and states of affairs in the world.

Perhaps it is less evident that attitudes should be an essential part of a worldview than that beliefs and values should be. Therefore, let me give a couple of examples of what I have in mind and why I claim we consequently cannot omit attitudes if we want to understand people's worldviews or outlooks on life. Thomas Nagel writes:

I want atheism to be true and I am made uneasy by the fact that some of the most intelligent and well-informed people I know are religious believers. It isn't just that I don't believe in God, and, naturally, hope that I'm right in my belief. It's that I hope there is no God! I don't want there to be a God; I don't want the universe to be like that. (Nagel (1997), 130)

Nagel does not simply disbelieve in God's existence; he goes further and takes a certain attitude towards God's existence: he does not want God to exist. Nagel also wonders whether any atheist or secular person really could be indifferent. But there are at least some such people who have stated that they do not care whether there is or is not a God. Such a view has been called 'apatheism' - a stance that expresses apathy towards belief in God (Hedberg and Huzarevich (2017)). An apatheist simply does not care whether there is a God or not. We can also assume that there are secular people who are atheists but regret - and do not celebrate - the 'death' of God. Charles Taylor agrees, and writes that, in a secular age, there will be people 'who feel bound to give it [belief in God] up, even though they mourn its loss' (Taylor (2007), 3). He seems to think that this might primarily be due to the social pressure of a secular society. Maybe so, but another possibility is that these atheists think that there are, albeit sadly, enough good reasons to believe that there is no God, that reality does not admit of one. Such secular people are reluctant atheists, whereas those whom Nagel exemplifies are relieved atheists. Either way, attitudes shape their secular worldviews in different ways. Attitudes could also be directed towards life in general. During much of Nagel's life, he has thought that life is absurd (Nagel (1971)). Existentialism is a worldview famous for emphasizing how vital angst should be in an authentic outlook on life.

Religious faith is another example of the relevance of attitudes when we try to explicate people's worldviews. Most theists do not merely believe that God exists but also think it is appropriate to adopt particular attitudes towards this truth. A person only has genuine religious faith, on such an account, if she loves and trusts God, or prays to or worships God. Attitudes towards God play a central role in how these people understand reality. It is consequently of utmost importance to identify this feature when we try to describe their worldview. The form of secular faith that Martin Hägglund thinks we should have (instead of religious faith) is also tied up with a particular attitude. He writes: 'My point ... is that if 
you care for our form of life as an end in itself, you are acting on the basis of secular faith' (Hägglund (2019), 9). It is the sense of finitude, of being devoted to a life that will end, that is at the heart of secular faith. Devotion towards finite life is a crucial ingredient of Hägglund's secular worldview.

Attitudes, beliefs, and values are central features that a proper understanding of a worldview must take into account. But, as I have already hinted, it is unreasonable to think of or construe worldviews in such a way that all our attitudes, beliefs, and values are included. One reason to add some constraints is that if a worldview were to be the totality of attitudes, beliefs, and values, then no two persons would share the same worldview. Each of us would have a unique worldview. But we want a notion which makes it possible for people to hold a worldview in common. When there is enough overlap of attitudes, beliefs, and values, we want to be able to say that people share the same worldview, even if they do not agree on everything.

Moreover, it is the centrality in a person's life of her identity and relation to others that determines whether certain beliefs, values, or attitudes belong to her worldview. Still, it might be useful to distinguish between what lies closer to the core or centre of a particular worldview and what is more peripherally located. When it comes to worldviews, some things lie closer to people's hearts than other things do. We could say that their degree of concern varies. For some people, it is God and their relationship to God that is at the centre; for others, it is the environment and climate change, or women's equality and rights, or the fight against poverty and racism, or for that matter becoming rich and famous, and for yet other people, it is hedonism, consumerism, or nationalism that is at the core of their worldview.

Let me also say a few words about part (c) in the definition. How one understands the nature of language and knowledge and their limits could play an essential role in people's worldviews. Some people think that science sets the limits for what we can know about reality. What science cannot discover, we cannot know anything about. ${ }^{4}$ Such an epistemic position limits drastically the kinds of beliefs that could be part of one's worldview. For instance, if God, the self, free will, and human rights are not within the purview of science, then we cannot know that God exists, that we have a self and a free will, or that there are human rights. Some religious persons take religious language to consist primarily of metaphors. They utter doctrinal sentences and participate in professions and ceremonies where those statements find their home, but disavow any interpretation of these statements that implies substantive doctrines about a transcendent reality. These religious symbolists could maintain that God is beyond or without being. Thus we cannot say anything about God other than that God is the ground of being or being itself. ${ }^{5}$ Hence, both our explicit or implicit epistemology and semantics could shape our worldview in profound ways.

As I have defined it, a worldview does not have to be something its adherents have consciously chosen to embrace. It might be; but many people's worldviews remain simply a background or horizon of which they are only vaguely aware, but which still guides how they perceive the world and what they do. Or things might just as easily be the other way around, so that people's outlook on life mirrors their behaviour. The traffic goes, so to say, both ways: not merely from what is taken to be true to action (from belief to practice), but also from how people live their lives to what they thereby take to be true (from practice to belief).

Further, a worldview is not something we easily and frequently change into another worldview, but rather is something that is part of our cultural inherence or social upbringing. This also explains why aspects of it are often hidden from us - it is simply a part of what we take for granted in life. Still, people do change worldviews: a Muslim could become a secular humanist, or vice versa. Conversion is a real possibility, today 
more than ever before. Previously, a person could go through life without much reflection, simply assuming the accepted worldview. Today, as Peter Berger (2014) emphasizes, people are thrown back on their own resources. What am I to believe? How should I act? Indeed, who am I? Of course, people are held back by restraints arising from their reasoning, upbringing, family, and need for stability in life. Yet the awareness that one could change one's worldview is there all the time, and thus the possibility is open that one might change one's choices at some point. The plurality that characterizes our contemporary society increases people's ability to make choices between and among worldviews.

Also possible are changes within a worldview, and this is something we need to consider. For instance, one could change some of one's values or ideas about who we are, or our attitudes to the environment. Many Christians in the West have not abandoned their Christian faith but have rejected the anthropocentric view of nature, in which only humans are assumed to have intrinsic value, and have replaced it with a biocentric or ecocentric view of nature, in which other things besides humans have a value of their own. Many too, over the last thirty to forty years, have also significantly changed their view on sexual minorities. Worldviews are not static, but are dynamic phenomena that respond to changes in society and to things in people's personal life history.

This means that we need to distinguish between worldview formation - questions about the origin of people's worldviews and how they are maintained over time; worldview configuration - questions about the specific content of their worldviews and how these things fit together; worldview revision or development - questions about how and why people change the content of their worldview; worldview conversion and transmission - questions about how and why they move (if they do) from one worldview to another and how a worldview is transmitted to the upcoming generations; and worldview justification - questions about how people justify or motivate their choice of or adherence to a particular worldview, or to a specific configuration of one particular worldview.

One problem with using the notion of worldview as an umbrella term to cover both religious and nonreligious people's outlooks on life is that there is a fundamental ambiguity in how the notion is used in contemporary society. On the one hand, people talk about a 'scientific worldview', which means the picture of the universe that emerges if we bring together the different theories of physics, astronomy, biology, sociology, and so on into a systematic whole. On the other hand, and in line with how the notion is used here, we can find people making statements about the embeddedness of science within a particular worldview, such as Christianity, Islam, or naturalism.

If, as I think we should, we understand the concept in the second way, it follows that science alone cannot provide us with a worldview, even though science can contribute to the formation or revision of a worldview. This is so because this conception entails that science lacks certain features that characterize a worldview. It is a matter of dispute what these features are exactly, but two elements science seems to lack are values and metaphysics. In this sense (and as I have defined it), a worldview tells us who we really are, what the world is ultimately like, and what we should do to live a satisfying life. It gives our life direction and meaning and thus provides us with values. But science essentially gives us facts and not values. It does not tell us how we should live or what we should ultimately value in life. Therefore, science does not qualify as a worldview. ${ }^{6}$

Moreover, no scientific discipline can tell us whether the physical universe is all that there is. If scientists make such an assertion, they make a metaphysical rather than a scientific claim. Theism and naturalism, on the other hand, each offer us an answer to this kind of question. Theism tells us that reality consists of God and all that God has made. Naturalism tells us that, ultimately, reality consists of nothing but matter or physical particles in motion. Therefore, these are worldviews, whereas science is not. Some advocates of scientism question this, arguing that the boundaries of science can be expanded in such 
a way that it can offer us both values and metaphysics (Rosenberg (2011) and Wilson (1998)). However, this view is highly controversial, lacking scientific consensus. Therefore, as scholars, we should refer to it as a 'scientistic' rather than as a scientific worldview.

Consequently, within worldview studies, we should try to avoid talking about a scientific worldview, and we must not compare a scientific and a religious worldview ${ }^{7}$ and see them as rivals. We can instead compare religious worldviews with secular worldviews, and we can ask what relevance science has for the formation, configuration, and justification of such types of worldview. In some of them, science plays a much more profound role than in others. Some people try to derive their worldview from science (as do adherents of scientific naturalism or scientism). Others are guided by science in the formation and configuration of their worldview (as are liberal naturalists and religious naturalists), whereas the objective of yet others is to express a worldview that is merely compatible with science (such as secular humanists, Christian theists, and Islamic theists).

Evolutionary biology cannot then be a worldview, but, arguably, Darwinism can. Brian Baxter maintains that 'many thinkers have developed from his [Darwin's] account of the origin of species, especially applied to our species, a distinctive perspective on the universe that merits the label "worldview"' (Baxter (2007), 1). Baxter takes a worldview to be a synoptic account of the basic features of reality and how we, and what has value, are related to that outlook on life. Similarly, Daniel C. Dennett holds that Darwin's 'dangerous idea' is an idea 'bearing an unmistakable likeness to universal acid: it eats through just about every traditional concept, and leaves in its wake a revolutionized worldview, with most of the old landmarks still recognizable, but transformed in fundamental ways' (Dennett (1995), 63). Both Baxter and Dennett, in their different approaches, try to develop and defend a Darwinian worldview. While we cannot properly talk about a scientific worldview, we can talk about a Darwinian worldview if we understand worldview in the way I have proposed. It would be one example of how a worldview can be designed: one which is heavily influenced by science, particularly, in this case, by evolutionary biology.

Another challenge we face, as I see it, is that the choice of the notion of worldview might lead one to think that a worldview must be all-embracing. So, we expect and countenance only those outlooks on life that contain a whole way of looking at ourselves and our world, or express our overall view of the nature of reality. This is, of course, what we as philosophers are particularly interested in, but not all people have such a comprehensive worldview. Some people have some ideas about human nature and what is good in life, but no clearly identifiable overall view of the nature of reality. Do such people not have a worldview ${ }^{8}$ I claim that we should resist defining and understanding the notion of worldview in such a way as to entail that they do not. Recall that the core idea is that all people - whether or not they are religious - express, through their actions and what they say, a particular understanding of what the world is like, what we ourselves are like, what is most important about the world, what our place in it is, and what we must do to live a good life. While a person's 'understanding' might be limited or partial in several ways, it is nonetheless about these important issues in life: it is still a worldview. Hence, we should not be misled into thinking that worldviews have to be comprehensive: we must allow that they might merely consist of quite loosely interconnected attitudes, beliefs, and values central to how individuals understand and live their lives. Perhaps we might, as I have suggested elsewhere, talk about 'worldview fragments' or 'fragmentary worldviews' in this context (Stenmark (1995), 239). ${ }^{9}$ But if we want to understand the notion in a similar way in both philosophy of religion and religious studies, ${ }^{10}$ we should acknowledge that worldviews can be more (or less) comprehensive, or more (or less) fragmentary. 


\section{Worldview formation and configuration}

Worldviews differ when it comes to their content or configuration, and that, of course, is what makes them different worldviews. Despite this, I suggest that we can distinguish between certain aspects that constitute central elements in a worldview. However, before exploring what these elements might be, let me say something about the importance of narratives in worldview formation and maintenance.

For most of us, presumably, our worldview does not primarily consist of a set of (more or less) interconnected beliefs and values - a product of our thinking. Rather, our beliefs and values are experienced, absorbed, and expressed in the course of life. (Even though this does not stop philosophers from identifying ideas or thought structures, inferred from how people talk and live their lives.) For this reason, the narrative form of worldview is of great importance. A worldview is often transmitted to us through stories rather than through the grasping of abstract ideas. That this is the case is self-evident when it comes to those religions containing Holy Scriptures, such as Judaism, Christianity, and Islam. In these religions, narratives, for instance, of the creation of heaven and earth, of the exodus of the Israelites from Egypt, of the life, death, and resurrection of Jesus, or of God's revelation to Mohammad and his call to become God's last prophet on earth, all play a crucial role.

But stories also play an essential role in the shaping of nonreligious or secular worldviews. Edward O. Wilson maintains that when religious narratives are rejected and regarded as obsolete, evolutionary theory could replace them and play this role in people's lives. He writes: 'the evolutionary epic is probably the best myth we will ever have' $(1978,201)$. Wilson believes that secular people today could and should understand themselves and their lives in the light of an evolutionary narrative, not a narrative of creation. Mary Midgley emphasizes that scientific theories could fulfil such an existential role in people's lives. She writes:

The theory of evolution is not just an inert piece of theoretical science. It is, and cannot help being, also a powerful folk-tale about human origins. Any such narrative must have symbolic force. We are probably the first culture not to make that its main function. Most stories about human origins must have been devised purely with a view to symbolic and poetic fittingness. Suggestions about how we were made and where we come from are bound to engage our imagination, to shape our views of what we now are, and so to affect our lives. (Midgley (1985), 1)

Other sources of worldview formation and expression are, of course, literature and film. Martha C. Nussbaum seems ready to go so far as to say that some outlooks on life or truths about human life could be expressed only in terms of narratives (Nussbaum (1990), 5). Other philosophers such as Eleonore Stump are satisfied just to point out that we cannot grasp some aspects of a worldview - she exemplifies with a Christian understanding of suffering - if we ignore the unique resources that narratives offer us, in contrast to abstract and isolated propositions about God, suffering, and evil (Stump (2010), 1-81).

No matter which side we end up on in this debate, we have to consider that people's worldviews often have a narrative form. Such a narrative expression gives them an existential or coercive power that a set of carefully defined propositions, no matter how coherent, can never give. For this reason, it is crucial that we develop a narrative philosophy of religion (or of worldviews) as one of the approaches available for philosophical inquiry into religions (or worldviews). Mikel Burley defends such a view. He maintains that a narrative philosophy of religion 
is the type of philosophical inquiry into religion that, without becoming a work of narrative art itself, takes seriously the contribution of narrative sources to our philosophical understanding of religion and, in the course of developing a philosophical argument, engages with such sources in a sustained manner rather than, at most, citing them only cursorily as mere decoration. (Burley (2019), 6-7)

We have so far considered, without my explicitly saying so, four of the six dimensions of worldview that Smart identifies. These six are: (1) doctrinal or philosophical, (2) mythic or narrative, (3) ethical or legal, (4) ritual or practical, (5) experiential or emotional, and (6) social or institutional (Smart (1995a), 7). ${ }^{11}$ Smart is, of course, right in that worldviews have both a ritual and a social dimension too. This is self-evidently true of traditional religions such as Christianity and Islam, but it is a factor that some people with a secular outlook on life have also recognized as being essential. Some have tried to develop substitutes for religious rituals and organizations or associations. Secular organizations have started to offer alternatives to religious confirmation and funerals, and aim to meet people's need for belonging by establishing gatherings such as the Sunday Assembly or the Church of Perpetual Life and by developing secular forms of spiritual practices. The secular philosopher Philip Kitcher even thinks that the roles religion fulfils in human lives in these regards constitute a severe challenge to secular worldviews. Atheists have to offer something to replace these social and experiential functions of religion and provide secular surrogates. He writes: 'Religious institutions connect their members, providing a sense of belonging and of being together with others, of sharing problems and of working cooperatively to find solutions' (Kitcher (2011), 35). A 'challenge for secularism', as he puts it, is to provide secular forms of community and a sense of belonging that can replace the religious ones.

Scholars of different kinds will be interested in different dimensions of worldviews. Perhaps we can say that our focus could be either more practically oriented or more theoretically oriented. Typically, philosophers are more interested in the intellectual aspects of people's worldviews, while sociologists might focus less on beliefs and much more on behaviour and belonging. In other words, we have both philosophical and empirical worldview studies.

What can we then say about the intellectual aspects of worldviews, about the kinds of beliefs they contain? I suggest that we identify specific clusters of questions or central topics and then use these as tools to identify the theoretical content of different worldviews. ${ }^{12}$ We will then be able to compare them, see where they differ and where they offer overlaps, and determine how comprehensive they are. There is nothing original about my account, rather I would say, like most philosophers presumably, that these issues and topics would at least include: ${ }^{13}$

- A view of the basic constitution of reality, or an ontology. (Does God exist, or do physical particles lie at the root of everything? Is nature God's creation or God's body, or is it a brute state of affairs that exists for no reason? Are all causes material or physical, or are there also non-material or mental causes in the world? What is the relation between the natural world and the social world? Is there an afterlife? Do spiritual processes and phenomena such as reincarnation, laws of Karma, psychics, ghosts, aura, or channelling exist, or do they not?)

- A view of human nature, or philosophical anthropology. (What characterizes humans in contrast to other living things? Are male and female naturally given subgroups of humans, or are they social constructions? What is the human condition? Do we have free will? Are we morally good or evil, unselfish or selfish creatures? Who is normal, 
and who is abnormal? Are there different races, and what, if anything, does that imply?)

- A view of society or political ideology. (When is a society well-ordered and just? What role should our worldview commitments play in the public sphere? Should the state provide us with welfare and health care, or should it primarily protect our freedom and fundamental rights? Should our loyalty, devotion, or allegiance to a nation outweigh other individual or group interests?)

- A view of history. (Is time a linear or cyclic process? Is it God's will, Karma, people's ideas, or economic forces that shape historical developments?)

- A view of the environment, or an environmental philosophy. (Is nature a resource we can use in any way we want? Are humans the only species of intrinsic worth on this planet? Is nature robust or fragile? Does climate change constitute a severe threat to human society and life on earth?)

- A conception of the good, or an ethics. (What is good and evil? Is what is right getting what you want; or is it a matter of obtaining happiness, of living an authentic life, or of establishing a personal relationship with God; or is it escaping the wheel of samsara - the cycle of repeated birth? Moreover, are values objective or subjective, something we discover, or something socially constructed?)

- A conception of the meaning of life. (Is human life meaningful or meaningless, or is life absurd? What is it that makes life meaningful or meaningless? Do we exist for a reason, or is our existence merely the result of material processes that did not or could not have us in mind?)

- A view of knowledge, rationality, and truth, or an epistemology. (Does science set the limits for what we can know, or are there other sources of knowledge besides science? Is there a difference between knowledge and rationality or reasonable belief? What is truth? Is truth deemed important or irrelevant in our choice of a basic outlook on life?)

- A view of language, or semantics. (Are words and concepts mental representations of reality, or are they merely tools for communication and coping? Is God ineffable, so our talk about the divine must be irreducibly metaphorical? Is religious language useful fiction and religious life a game of make-believe?)

I take these to be central themes or topics that contain several different questions, some of which I have exemplified within the brackets above. Philosophers would reflect and care more about some of these topics and questions than would people in general. Moreover, some of the themes would be topics or questions more central to some worldviews than to others.

Ann Taves $(2020,138)$ suggests that we can narrow these questions and topics down to six Big Questions (BQ):

REALITY (ontology): What is ultimate reality? What exists? What is real?

RIGINS (cosmology): Where did it come from? How did we get here? (Where is 'here'?) Where are we going?

KNOWLEDGE (epistemology): How do we know this (about ourselves and reality more generally)?

SITUATION: What is the situation in which we find ourselves? (Who are 'we'?)

GOAL (axiology): What is the good (the goal) for which we should strive?

PATH (praxeology): What do we need to do to reach the goal? What path should we follow? How do we ensure that we are on the path? 
Perhaps this kind of reduction is possible, but what we must keep in mind is that a worldview - as I have described it - contain those beliefs, values, and attitudes that are of central importance for how people understand their lives and live them. Therefore, answers to some of these Big Questions might not even be an implicit part of some individuals' actual worldview. For instance, they might never have thought about what ultimate reality is nor can we necessarily derive an answer to that question from what they believe and how they behave.

\section{Religious and secular worldviews}

Philosophers and other scholars are becoming increasingly interested in how secular alternatives to religions are understood and materialized in contemporary society. What we gain by using the notion of worldview - rather than the notion of religion is an analytical category where both religions and secular outlooks on life (what sociologists call 'nonreligion') can be studied in positive terms. This makes it possible for us to identify features we wish to compare critically and constructively, and allows us to study worldviews or outlooks on life without worrying whether they are religious or not. That is a good thing: but, at the same time, we still face the question of how to distinguish between religious worldviews (or religions) on the one hand and secular worldviews (or nonreligions) on the other. We perhaps, for instance, want to know what the difference is between religious humanism and secular humanism. Of course, there will always be a grey area where it will be hard, perhaps even impossible, to classify, non-arbitrarily, a way of life as being religious or not. Where, for example, would those people who say that they are spiritual but not religious belong?

One way of formulating the difference would be to say that a religious worldview affirms, at least, that reality has a transcendent, divine, or spiritual dimension, which, roughly speaking, could be taken to mean, as Keith Ward puts it, that:

there is a non-physical reality (or realities) that is of supreme value and that humans can become aware of through various forms of prayer or meditation. In the great religious traditions, this supreme value is said to have the nature of consciousness, intelligence, compassion, and bliss. Human awareness of it is meant to lead to the realization of those qualities in the human world and to the cessation of forms of egoism and selfish desire. (Ward (2008), 4)

We then add, alongside this characterization, that, in contrast, a secular worldview denies that reality is constituted in such a manner.

One problem with this way of understanding the difference between a religious and a secular worldview is that the latter gets merely negative content. But if people unavoidably express in their way of living an understanding of who they are, of the larger setting of which they are a part, and of what has value in life, and accordingly how life should be lived, then it must also be possible to express secular worldviews in positive terms. The question is: what, more precisely, is this positive content, and thereafter, what should we call such outlooks on life and those who hold them? No matter what terminology we use, we will run into problems. As I have already indicated, I propose that we use 'secular' as the contrast to 'religious'. Religious people should not be contrasted to nonreligious people or religious nones but to secular people. The worldview which - consciously or unconsciously - the latter embrace or develop in their lives ought not to be called a nonreligious worldview but a secular worldview. If we do so, we can also talk about secular believers, secular faith, secular rituals, ceremonies, and gatherings. (I shall return to some of the problems this terminology creates.) We can then distinguish between two 
types of worldview - not denying that there are many borderline cases. How to specify the distinction is not easy, but we could say roughly that:

Religious worldviews affirm the existence of a transcendent, divine, or spiritual dimension of reality and its importance for how we understand and live our lives.

Secular worldviews deny the existence of a transcendent, divine, or spiritual dimension of reality and affirm that reality has a different makeup, and it is the basic features of this reality that have importance for how we should understand and live our lives.

Secular people can understand this alternative outlook on reality in differing ways. The worldview that most reflective atheists in the Western world embrace today contains, again roughly, the view that reality is made up entirely of physical particles in fields of forces brought into existence in the Big Bang, and that we must understand ourselves and how we should live our lives against this background. Nature is all there is and ever will be. Within philosophy, we typically call this secular worldview naturalism. Julian Baggini exemplifies it when he writes: 'What most atheists do believe is that although there is only one kind of stuff in the universe and it is physical, out of this stuff come minds, beauty, emotions, moral values' (Baggini (2003), 6). Naturalism could, of course, be developed in different ways, but two of the more influential are scientific naturalism and secular humanism. Scientific naturalists privilege science in all areas of life and are consequently suspicious of everything else. Science alone should be our guide for understanding the world we live in and how we should live our lives. Secular humanists, on the other hand, reject the hegemony of science. They instead maintain that secular people should be guided by humanism in their lives: by a belief in human freedom, autonomy, and dignity. Consequently, in their worldview formation, they emphasize culture more than the natural order discovered by the sciences. ${ }^{14}$

The group of worldviews that naturalists primarily reject are theistic worldviews. We could say that theism is the religious worldview that affirms that there is a God or an all-encompassing divine mind who is the creator of the world, and that the highest good for human beings is to be in proper relationship to this divine reality. Much research within the philosophy of religion is about how to think about the configuration or content of theism, and whether or not it is a better-justified worldview than is naturalism.

However, secular worldviews also reject those religions in which God plays no central role or in which God's existence is denied. Within the philosophy of religion, atheism is understood as a rejection of monotheism. If atheism were to also cover the option of rejecting gods such as Aphrodite, Shiva, or Thor, then many Christians, Jews, and Muslims would be atheists. This would complicate the philosophical debate about theism and atheism: we would then have to keep track of those particular gods in respect of which someone is an atheist or a theist. However, within a global philosophy of religion, and certainly within religious studies, things become more feasible if we understand an atheist as someone who denies the existence of both God and gods. Naturalists go further and reject all religions, even those in which belief in gods lack importance, such as Buddhism or Advanta Vedānta in Hinduism. They also reject animistic belief-systems: those containing belief in innumerable spiritual beings involved in human affairs and capable of helping or harming human interests. While none of the major world religions are animistic (though they may contain animistic elements), most indigenous religions are. Animism can also be found in many forms of so-called New Age spirituality. Naturalists believe neither that agents such as gods, goddesses, spirits, guardian angels, and ghosts, or phenomena or processes such as Karma, reincarnation, channelling, and auras are a part of the natural order; nor that the natural order is a creation of God. According to 
my proposed definition, this understanding of reality is not merely a characteristic of naturalism but characterizes all secular worldviews. As naturalists like to express it, naturalism excludes not merely theism but all forms of supernaturalism (de Caro and Macarthur (2004), 2-3). Some philosophers of religion have instead proposed that we should talk about 'non-theism' (Wainwright (1999), 10 and Griffiths (2005), 59f.). We would then have at least two fundamental kinds of religious worldviews, theistic and nontheistic worldviews, to be contrasted with secular worldviews such as scientism and secular humanism.

The distinction between atheism and naturalism is essential in two ways. The first is that if we understand atheism as merely a negative claim - an atheist denies the existence of God and gods - then it cannot constitute a worldview. In contrast, naturalism can, since it also contains positive claims. The second is this: if atheism simply entails the denial of the existence of God and gods, then an atheist might still accept the reality of Karma, reincarnation, channelling, or auras. This is one reason why certain forms of Buddhism and New Age spirituality might be atheistic yet still be classified as religious. A naturalist must, in contrast, reject all of these spiritual dimensions of reality.

What about agnosticism? Where do agnostics belong? Do they embrace a secular worldview, so we have, on one side, atheists and agnostics, and, on the other, theists? Some definitions of atheism entail such a classification. When someone claims to be an atheist in the Oxford Handbook of Atheism's sense, she has failed to come to the belief that there is a God or gods (Bullivant and Ruse (2013), 2). Atheists can then be disbelievers or unbelievers, but it is enough that they are nonbelievers and lack a belief in God (or gods). Thus, agnostics are a subgroup of atheists, and they will consequently have a secular worldview.

But there are at least two problems with such an understanding of atheism and agnosticism. The first is that an agnostic may maintain, as does Anthony Kenny, that there are 'significant differences between the two positions; and the differences show agnosticism, if carefully defined, to be both epistemically and morally preferable to atheism' (2009, 117). So agnostics can be just as critical of atheists as of theists. The second and more important problem for our purposes is that it is quite possible to be a religious agnostic. To take one example, Paul Draper thinks that there are several good arguments for theism but also several good arguments for atheism or naturalism. So, neither theists nor atheists have been able to convince him that they are right. At the same time, this does not stop him from identifying with a religious outlook on life and from prayer, because he regards 'God's existence as a real possibility', so 'there might be a God listening. More generally, I ought to do what I can to cultivate or at least prepare for a relationship with God' (Draper (2002), 210). The possibility of this agnostic stance is also exemplified by the recent focus within the philosophy of religion on non-doxasticism (Audi (2011), 51-88 and Palmqvist (2019)). According to doxastic or belief-based religion, belief is necessary for authentic religious life. In contrast, a non-doxastic understanding of religion, or beliefless religion, takes a weaker epistemic attitude, such as hope or acceptance, together with appropriate behaviour, to be sufficient. But then again, the agnostic might hope that there is no God, have no desire for religious life, and thus dismiss prayer or any other religious activity. Consequently, we need to distinguish religious agnostics from secular agnostics, with only the latter having a secular worldview.

Moreover, we should not overstate the strength of the epistemic commitment that theists, atheists, and agnostics make. It is undoubtedly true that some theists maintain that they know (or that we all can know) that God exists, some atheists think that they know (or that we all can know) that God does not exist, and some agnostics believe that they (or even any of us) do not know whether or not God exists. But we must not fail to recognize those of them who merely claim that it is reasonable or rational for them to believe that the central propositions of their religious or secular worldview are true. For this reason, we should take a theist to be someone who believes that God exists; an 
atheist to be someone who does not believe that God exists; and an agnostic to be someone who simply neither believes nor disbelieves in the existence of God. Notice that we fail to identify many agnostics in our society if we neglect to take that into account. Joseph O. Baker and Buster G. Smith write that they consider 'agnostics to be those who believe knowledge of god's existence or nonexistence is beyond human capacity' or believe that 'theistic claims are unverifiable in principle' (Baker and Smith (2015), 15). Hence, on this viewpoint, only someone who answers a survey question about God's existence by selecting an option such as 'I don't know, and there is no way to find out' is an agnostic. But this is poor sociology, leaving large groups of agnostics out of the picture: people who simply neither believe nor disbelieve in the existence of God. For some of them, it might remain a real possibility that God may exist. They might also hope that they will come to believe in God before their lives come to an end, and, in the meantime, participate in religious activities and be members of religious congregations.

Religious agnosticism is about relating positively to a religious outlook on life that might, for all one knows, turn out to be true. In contrast, secular agnosticism is about relating positively to a naturalistic outlook on life that might, for all one knows, turn out to be true. We can borrow a term from Lynne Rudder Baker and say that secular agnostics embrace near-naturalism (Baker (2017), 348). This is the stance that remains quiet about anything transcendent yet refrains from taking a stand on whether nature is all there is and ever will be, since its defenders typically think there is insufficient evidence for such a view, while still living as if a naturalistic worldview is true. Religious agnostics, in contrast, live as though a theistic worldview is true: they embrace near-theism. Another option for some religious agnostics is to live as though a nontheistic worldview is true, rejecting both naturalism and theism, and yet desiring that there might exist a non-divine but transcendent or spiritual dimension of reality, and thinking this to be epistemically possible. There might be a reality which could contain the laws of Karma, reincarnation, disembodied spirits, auras, or channelling; and it is this constitution of reality that should have importance for how we live our lives. Such people embrace near-nontheism.

Still, agnostic people do create a problem for the suggested distinction between religious and secular worldviews. According to the distinction proposed, religious people affirm the existence of a transcendent, divine, or spiritual dimension of reality and its importance for how we understand and live our lives. In contrast, secular people deny the existence of a transcendent, divine or spiritual dimension of reality, and affirm that reality has a different makeup. It is this different makeup that has importance for how we should understand and live our lives. As a paradigmatic characterization of religious and secular people, this is probably fine as it stands. However, the problem that remains is that agnostics do not deny the existence of a transcendent, divine, or spiritual dimension of reality but merely doubt its existence. But agnostics also fall short of affirming that reality is made up entirely of physical particles in fields of forces brought into existence in the Big Bang and that we exist for no reason, because they do not think there is sufficient evidence to support this worldview either. So, we have secular people who are agnostics and doubt (but do not deny) that there is a transcendent, divine, or spiritual dimension of reality and live their lives as though such a dimension lacks importance. And, likewise, we have religious people who are agnostics and doubt (but do not deny) the existence of a transcendent, divine or spiritual dimension of reality, but still live as though such religious reality is significant for their lives. We must either accept this ambiguity or assume a weaker or more liberal interpretation of 'affirm' and 'deny' (which allows for a weaker epistemic attitude than is implied by the word 'belief'). 
So, both belief (and sometimes weaker epistemic attitudes such as hope and acceptance) and behavior (people's way of living) are essential when identifying and distinguishing between religious and secular worldviews. But what should we say about the third of the 'three B's' that sociologists of religion focus on in their study of religion, namely belonging? I suggest that we restrict the notion of 'nones' to this aspect of people's worldview, since a person cannot be without life-orienting beliefs and behaviour. Anyone can, however, choose to belong or not to belong to a religious or secular organization or community. However, given that we distinguish, as I argue, between religious and secular worldviews, and not between religion and nonreligion, our understanding of religious nones will need to change. Religiously non-affiliated people are individuals who self-identify as religious but have no affiliation with an organized religious practice or community. These persons are 'religious nones'. Secularly non-affiliated people are individuals who self-identify as secular but have no affiliation with an organized secular practice or community. These persons are 'secular nones'. Most religious people are affiliated in some way, but most secular people are not. There are many secular nones, but fewer religious nones. The group of religious nones is nevertheless growing. Perhaps it is for some of them the first step in their - conscious or unconscious - transition from a religious to a secular outlook on life.

Suppose we choose to name the alternatives to the religions of the world 'secular worldviews' and reject the terms 'nonreligions' or 'nonreligious worldviews'. In this case, we have to be quite careful how we use the notion of secular and, to some extent, also go against current usage. For instance, a secular society or state cannot any longer be one that aims at being neutral with respect to the worldviews that set us apart one from another, but must be a society in which secular worldviews are taken to be the default position (arguably as Sweden is today but the USA is not). Understandably, this traditional way of talking about the state as secular is widespread because, in the original cases, the views about which the state ought to be neutral were all religious views. But, and this is important, that is no longer the case. Today there is available a great variety of secular outlooks on human life, and there are many nonreligious citizens. Rather than using the notion of secular society in that traditional way, we should use it to refer to a particular change in Western society, namely, that a growing number of people in some parts of the world do not consider themselves to be religious when self-identifying.

What about secularism? Secular people might embrace secularism, but they need not do so; that is, they are not necessarily secularists in the sense of having an anti-religion stance. Secularism comes in many forms, but I would say that all its forms aim to minimize the influence of religion on society (or on all aspects of life) and hope that religion will one day cease to be a live option for people. Secularism's core idea is that we should actively strive to minimize the influence of religion, first on politics, and eventually on society as a whole; this is essential to the defence of science, democracy, and human flourishing. Society is better off without religion, because it is not merely false or, at the very least, irrational, but is also dangerous to human well-being and democratic society. We should, therefore, actively push history forward towards the goal of a nonreligious world.

However, secular people could, and many of them do, reject this vision of a future society without religion. They could be individuals who feel bound to give religion up, even though they mourn its loss. Or they might believe, as does the secular philosopher Jürgen Habermas, that secular Western society needs access to religious beliefs, values, and practices if it is not to cut itself off from key resources for creating meaning and identity (Habermas (2006), 10). So secularists are a subgroup within the larger group of secular people. 


\section{Different ways of studying worldviews and the task for philosophers}

Many scholars other than philosophers are also interested in studying people's worldviews. This means that they will use different approaches (anthropological, historical, psychological, or sociological) when they try to address those aspects of human life and those existential questions which people strive to grapple with and respond to: Who am I? Where am I going? How do I fit into the totality of things? How should I live my life, and how should I treat other people and other living creatures? Would it be better if I (or we) lived in another way than I (or we) do? Some scholars do surveys, others conduct interviews, yet others study texts of different sorts using discourse analysis, critical theory, or conceptual analysis. They also analyse different types of material: manifestos, literature, film, art; or study how these ideas are expressed in social media - on TV, Facebook, Twitter, or in the professional writings of scientists, philosophers, or theologians. Moreover, scholars might focus on a particular aspect of a worldview, such as its narratives, its theory of human nature, its conception of God, its rituals, or modes of belonging.

Philosophers have mainly been interested in studying intellectually reflected or deliberated worldviews. They analyse the sorts of worldviews which their fellow philosophers, theologians, scientists, or other intellectuals have articulated and defended or criticized. If these worldviews contain contradictions or tensions of different kinds, philosophers frequently rationally reconstruct them, so they become as coherent or free from inconsistency as possible, given the limitations the material sets. They do no empirical surveys, nor do they study what kinds of worldview people in general have in a particular society, nor compare them to what a similar group of citizens thought about these issues twenty years earlier.

In contrast, the worldview of many people, perhaps most, is not something they themselves have thought much about. When sociologists interview someone to identify the contours of their outlook on life, this might actually be the first time that person has tried to articulate their worldview and express it coherently. Not only can worldviews be more or less comprehensive or fragmentary, but they can also be more, or indeed less, a product of deliberation or intellectual consideration. ${ }^{15}$ We have both reflective and unreflective worldviews, and everything in between.

Furthermore, we can choose to study articulated worldviews, whether expressed in writings or merely verbally, or can be more interested in lived worldviews, that is, as they are acted out in practice. ${ }^{16}$ People frequently enact aspects or elements of their worldview without articulating them. An articulated worldview might be identical to the lived worldview, but it could also differ significantly. What we say and what we do are not always the same thing. It is also reasonable to think that a lived worldview is more fragmentary, incoherent, and situation-dependent than is an articulated worldview. A higher degree of systematization, coherence, and situation-independence almost automatically follows when we start to reflect on something and express it in words. Cognitive and moral dissonances are easier to detect when we verbalize our ideas and describe our patterns of behaviour.

Both distinctions admit of degree: people's worldviews could be more or less comprehensive and could contain more or less discrepancy between what is said and what is done. However, the first captures mutually exclusive alternatives (an individual's worldview cannot at the same time be both intellectually elaborated and unreflective), whereas the second does not (a person's articulated and lived worldview can be the same).

An academic study of worldviews also needs to consider that certain parts of people's worldviews are more or less manifest, whereas others are more or less latent or hidden. Groups of religious or secular people may want us to know only some things about the 
content of their worldview. Other things might become revealed if we study texts, speeches, or behaviour patterns that aim to communicate adequate beliefs, values, attitudes, or ways of behaving to the in-group alone. The distinction between manifest worldviews and hidden worldviews is perhaps especially important when we study what could be dubbed 'forbidden worldviews', such as racism, sexism, radical forms of environmentalism (such as the Earth Liberation Front), or militant forms of religion (such as ISIS). These are worldviews or parts of worldviews, which are neither socially or morally accepted, nor legitimate to embrace in a particular society.

What, then, characterizes philosophical worldview studies and makes this discipline different from a religious studies approach to worldviews, or from what I previously called empirical worldview studies? I propose that they differ in at least two ways: ways that make them complementary rather than rivals, although the second way contains (surprisingly for many philosophers) a more controversial claim. Let us start with what is not controversial. Philosophers are primarily interested in the first of the 'three B's', belief, rather than the other two, behaviour and belonging. Moreover, they are, in particular, interested in intellectually elaborated versions of people's worldviews. These could be the secular worldviews of public intellectuals such as Richard Dawkins or Sam Harris, but are more typically those of philosophers such as Philip Kitcher or Thomas Nagel (and sometimes these categories coincide, as in Bertrand Russell or more recently Martin Hägglund). Researchers in religious studies are interested in all three of the B's, but when they are interested in religious belief and secular belief, the emphasis is on what people in general believe or what major subgroups of them believe. Is it the case that more people today embrace or try to develop secular alternatives to the world's religions, and if so, what do they, more exactly, believe? Having such a focus implies that the worldviews which they study are often less reflected, comprehensive, systematic, and coherent than are those which philosophers study. But studies of both kinds are important.

Now to the more controversial part. Religious studies are taken to have essentially two aims: one is to understand the world's religions in all their diversity, and the second is to explain why religions (or subgroups of them) arise, how they develop and are transmitted, why they attract people or why they decline and perhaps perish. When it comes to the aim of understanding, there is a significant overlap with philosophy, in that hermeneutics and phenomenology are of great relevance. Conceptual analysis could also play a part here, but it seems less appreciated within religious studies than are those other two strands. ${ }^{17}$

One possible explanation of why people cease to be religious and perhaps become atheists and develop a secular outlook on life is science's success in explaining more and more of our universe. This might be the correct explanation. Still, philosophers are not satisfied and want to ask: 'Even if this is true, is it really a good reason for becoming an atheist and for developing a secular worldview?' Such a critical question indicates that philosophers are not satisfied with a form of worldview studies that does not critically assess the content of people's worldviews and their grounds, and which fails to explore what kind of criteria we could and should use when developing our own and evaluating other people's basic outlook on life. ${ }^{18}$ They want to complement a descriptive worldview analysis with a normative one. They see critical thinking or critical reasoning through logic and informal argumentation methods to be at the core of what philosophy is. In fact, philosophers in their inquiry presuppose that a third aim of religious studies or, more broadly, worldview studies, should be to critically and constructively evaluate the world's religions in all their diversity, and likewise their secular counterparts.

This objective is highly controversial in religious studies circles, much being said about why that kind of philosophical inquiry (in contrast to say hermeneutics) should not be considered a proper part of religious studies. ${ }^{19}$ To understand the rationale behind this 
stance, we must consider that religious studies developed out of confessional theology and aspired to be a scientific discipline and not be seen as a part of Christianity or any other religion. ${ }^{20}$ Religious studies aims to be a scientific study in the sense that this form of inquiry does not require a particular faith commitment on the part of its practitioners, and it accepts only the methods of the social and human sciences. Religious studies does not focus merely on the home religion. It also aims to be neutral in that it contains only descriptions and explanations of diverse religious phenomena, and does not attempt to justify or reject them. Religious studies is not involved in any (positive or negative) apologetics. This is all understandable, but it is now time to move on and fully accept the philosophical study of religions and their secular counterparts as a proper part of worldview studies. At the same time, this often very negative attitude to critical philosophical reasoning within religious studies is hard to grasp for those philosophers of religion who work in departments of philosophy and never really engage academically with scholars other than their philosophical peers - peers who would never dream of rejecting the normative elements of philosophy. In fact, if the objection is that philosophical normative analyses of religions and worldviews are not a proper part of the human sciences, then it seems that philosophy, as it is currently practised, cannot be a part of those academic disciplines either.

Much bridge-building and serious attempts to understand the other groups of scholars involved in the emerging and much-needed field of worldviews studies are required in the future. But I am relatively optimistic. I hope that philosophers' contributions will be recognized and accepted outside their own disciplinary boundaries.

\section{Notes}

1. For a good and critical discussion of nonreligion, religious nones, religious nonbelief and so on, in the study of religion, see Lee (2015).

2. See the special issue 'Philosophy of Religions: Cross-Cultural, Multi-Religious Approaches', Religious Studies 56 (2020), 1-129.

3. In Sweden, for example, Anders Jeffner developed a research programme in 'livsåskådningsforskning' (Eng. 'worldview studies') in the 1970s. See, for instance, Jeffner (1981) and (1992).

4. This view is often called scientific naturalism or scientism. (See, for instance, de Ridder, Peels, and Woudenberg (2018).)

5. I have discussed this view of God in Stenmark (2015).

6. A discussion of this topic can be found in Matthew (2009).

7. Clément Vidal is making such a comparison in Vidal 2008.

8. One of the reasons why Sander Griffioen $(2012,10)$ denies that everyone has a worldview is that some individuals' outlooks on life lack this kind of comprehensiveness.

9. This is also highlighted by Bråkenhielm (1990), $109 \mathrm{f}$.

10. André Droogers and van Harskamp (2014) and Taves (2020) are three examples of scholars of religion who argue that religious studies should become worldview studies.

11. My main worry with Smart's definition is that it tends to bias the analysis of secular worldviews in a religious direction, but that would have to be the topic of a different article. Notice also that Smart offers a slightly different account of what a worldview is in Smart (1995b), 18-19.

12. An older account that resembles this one, is given in Jeffner (1981), 18-19.

13. A different attempt to identify these issues and topics but from a psychological point of view can be found in Koltko-Rivera (2004).

14. I have analysed in more detail their core commitments in Stenmark (forthcoming). John Gray (2018) differentiates between many other forms of atheism.

15. This is something I have previously discussed in Stenmark (1995), 238-239.

16. Normally this distinction is applied to religions. A 'lived' religion is one that is 'expressed and experienced in the lives of individuals' and not constituted by the beliefs, norms and practices promoted by religious organizations (McGuire (2008), 3). 
17. In a comprehensive introduction to the methods of religious studies, there are chapters on hermeneutics and on phenomenology but none on conceptual analysis (Stausberg and Engler (2014)).

18. Discussions of such criteria can be found in, for instance, Smart (1995c), Vidal (2012), Oppy (2017), and Wainwright (1999), 178-197.

19. An excellent discussion of these problems can be found in Schilbrack (2014), 175-204.

20. This attitude is sometimes reflected in the name of the journal of religious studies such as Journal for the Scientific Study of Religion.

\section{References}

Audi R (2011) Rationality and Religious Commitment. Oxford: Oxford University Press.

Baggini J (2003) Atheism: A Very Short Introduction. Oxford: Oxford University Press.

Baker LR (2017) Naturalism and the idea of nature. Philosophy 92, 333-349.

Baker JO and Smith BG (2015) American Secularism. New York: NYU Press.

Baxter B (2007) A Darwinian Worldview. Aldershot: Ashgate.

Berger P (2014) The Many Altars of Modernity: Toward a Paradigm for Religion in a Pluralist Age. Berlin: De Gruyter Mouton.

Bråkenhielm CR (1990) Constructive theology and the study of popular life-philosophies. Studia Theologica 44, 107-121.

Bullivant S and Ruse M (2013) The study of atheism. In Bullivant S and Ruse M (eds) The Oxford Handbook of Atheism. Oxford: Oxford University Press, pp. 1-21.

Burley M (2019) Narrative philosophy of religion: apologetic and pluralistic orientations. International Journal for Philosophy of Religion 88, 5-21.

Cottingham J (2014) Philosophy of Religion. Cambridge: Cambridge University Press.

De Caro M and Macarthur D (2004) Introduction: the nature of naturalism. In De Caro M and Macarthur D (eds) Naturalism in Question. Cambridge, MA: Harvard University Press, pp. 1-17.

Dennett DC (1995) Darwin's Dangerous Idea. London: Penguin Books.

de Ridder J, Peels R, and van Woudenberg R (eds) (2018) Scientism: Prospects and Problems. Oxford: Oxford University Press.

Draper P (2002) Seeking but not believing: confessions of a practical agnostic. In Howard-Snyder D and Moser PK (eds) Divine Hiddenness. Cambridge: Cambridge University Press, pp. 197-214.

Droogers A and van Harskamp A (eds) (2014) Methods for the Study of Religious Change: From Religious Studies to Worldview Studies. Sheffield: Equinox Publishing.

Gray J (2018) Seven Types of Atheism. London: Allen Lane.

Griffioen S (2012) On worldviews'. Philosophia Reformata 77, 19-56.

Griffiths PJ (2005) Nontheistic conceptions of the divine. In Wainwright WJ (ed.) The Oxford Handbook of Philosophy of Religion. Oxford: Oxford University Press, pp. 59-79.

Habermas J (2006) Religion in the public sphere. European Journal of Philosophy, 14, 1-35.

Hägglund M (2019) This Life: Secular Faith and Spiritual Freedom. New York: Anchor Books.

Hedberg T and Huzarevich J (2017) Appraising objections to practical apatheism. Philosophia: Philosophical Quarterly of Israel 45, 257-276.

Jeffner A (1981) Att studera livsåskådningar. In Reinhold Bråkenhielm C et al. (eds) Aktuella livsåskådningar. Karlshamn: Doxa, pp. 11-21.

Jeffner A (1992) A new view of the world emerging among ordinary people. In van den Brink G, van den Brom LJ and Sarot M (eds) Christian Faith and Philosophical Theology. Kampen: Kok Pharos, pp. 137-145.

Kenny A (2009) Agnosticism and atheism. In Cornwell J and McGhee M (eds) Philosophers and God. London: Continuum, pp. 117-124.

Kitcher P (2011) Challenges for secularism. In Levine G (ed.) The Joy of Secularism. Princeton: Princeton University Press, pp. 24-56.

Koltko-Rivera ME (2004) The psychology of worldviews. Review of General Psychology 8, 3-58.

Lee L (2015) Recognizing the Non-Religious. Oxford: Oxford University Press.

Matthew MR (ed) (2009) Science, Worldviews, and Education. New York: Springer.

McGuire MB (2008) Lived Religion. Oxford: Oxford University Press.

Midgley M (1985) Evolution as a Religion. London: Methuen.

Nagel T (1971) The absurd. The Journal of Philosophy, 68, 716-727.

Nagel T (1997) The Last Word. Oxford: Oxford University Press.

Naugle DK (2002) Worldview: The History of a Concept. Grand Rapids: Eerdmans.

Nussbaum MC (1990) Love's Knowledge: Essays on Philosophy and Literature. Oxford: Oxford University Press. 
Oppy G (2017) Rationality and worldview. In Draper P and Schellenberg JL (eds) Renewing Philosophy of Religion. Oxford: Oxford University Press, pp. 197-214.

Palmqvist C-J (2019) The proper object of non-doxastic religion. Religious Studies 55, 559-574.

Plantinga A (2011) Where the Conflict Really Lies: Science, Religion and Naturalism. Oxford: Oxford University Press. Rosenberg A (2011) The Atheist's Guide to Reality. New York: W.W Norton.

Schilbrack K (2014) Philosophy and the Study of Religions. Oxford: Wiley Blackwell.

Sire JW (2015) Naming the Elephant: Worldview as a Concept. Downers Grove, IL: IVP Academic.

Smart N (1995a) Worldviews. Englewood Cliffs: Prentice-Hall.

Smart N (1995b) The philosophy of worldviews - that is, the philosophy of religion transformed. In Dean T (ed.) Religious Pluralism and Truth. New York: SUNY Press, pp. 17-31.

Smart N (1995c) Choosing a Faith. London: Bowerdean.

Stausberg M and Engler S (eds) (2014) The Routledge Handbook of Research Methods in the Study of Religion. London: Routledge.

Stenmark M (1995) Rationality in Science, Religion and Everyday Life. Notre Dame, IN: University of Notre Dame Press.

Stenmark M (2015) Competing conceptions of god: the personal god versus the god beyond being. Religious Studies 51, 205-220.

Stenmark, M (forthcoming) Secular worldviews: scientific naturalism and secular humanism.

Stump E (2010) Wandering in Darkness: Narrative and the Problem of Suffering. Oxford: Oxford University Press.

Taves A (2020) From religious studies to worldview studies. Religion 50, 137-147.

Taylor C (2007) A Secular Age. Cambridge, MA: Harvard University Press.

Vidal C (2008) Wat is een wereldbeeld? ('What is a worldview?'). In Van Belle H and Van der Veken J (eds), Nieuwheid denken. De wetenschappen en het creatieve aspect van de werkelijkheid. Leuven: Acco, pp. 1-13.

Vidal C (2012) Metaphilosophical criteria for worldview comparison'. Metaphilosophy 43, 306-347.

Vroom HM (2006) A Spectrum of Worldviews. Amsterdam: Rodopi.

Wainwright WJ (1999) Philosophy of Religion. Belmont, CA: Wadsworth.

Ward K (2008) The Big Questions in Science and Religion. West Conshohocken, PA: Templeton Press.

Wilson EO (1978) On Human Nature. Cambridge, MA: Harvard University Press.

Wilson EO (1998) The biological basis of morality. The Atlantic Monthly, April, 53-70.

Cite this article: Stenmark M (2022). Worldview studies. Religious Studies 58, 564-582. https://doi.org/10.1017/ S0034412521000135 